\title{
SIMULATION OF PROFESSIONAL SITUATIONS \\ AT ENGLISH CLASSES FOR STUDENTS \\ OF TECHNICAL SPECIALTIES
}

\section{МОДЕЛЮВАННЯ ПРОФЕСІЙНИХ СИТУАЦІЙ \\ НА ЗАНЯТТЯХ 3 АНГЛІЙСЬКОЇ МОВИ ДЛЯ СТУДЕНТІВ ТЕХНІЧНИХ СПЕЦААЛНОСТЕЙ}

\section{Kateryna Halatsyn ${ }^{1}$}

\section{Alla Feshchuk ${ }^{2}$}

DOI: https://doi.org/10.30525/978-9934-26-049-0-17

Abstract. The paper reveals the role and importance of modeling of professional situations at English classes in higher technical education institutions. The professional situation is defined as purposeful modeling of professionally similar circumstances in the process of learning English and conditions of solving engineering and business tasks, making professional decisions, achieving a successful result of business communication.

The purpose of the paper is to analyze the content and requirements for modeling of professional situations in the process of studying English by the future specialists in engineering. Realization of the purpose demands performance of the following tasks: 1) define the essence of modeling of professional situations; 2) substantiate the conditions for effective modeling of professional situations at English classes in higher technical educational institutions; 3) offer examples of modeling professional situations at English classes in higher technical educational institutions.

In the process of scientific research the methods of analysis, synthesis, generalization, systematization, inference, observation have been used.

The components of the professional educational situation and the factors that need to be taken into account in the process of its use are identified. The

\footnotetext{
${ }^{1} \mathrm{PhD}$ in Pedagogical Sciences, Associate Professor, National Technical University of Ukraine

"Igor Sikorsky Kyiv Polytechnic Institute", Ukraine

2 Teacher,

National Technical University of Ukraine

"Igor Sikorsky Kyiv Polytechnic Institute", Ukraine
} 
examples of modeling professional situations during the study of the discipline "Practical Course of Foreign language for Business Communication" in higher technical education institutions are given. The forms of modeling of professional situations (individual, pair, group) which are directed on the formation of competences of professional English communication according to various roles of professional activity (head - subordinate, subordinate subordinate, subordinate - collective) are defined.

Special emphasis is focused on the examples of modeling of professional situations through the use of game modeling (role-playing games: controlled, improvised), method of case study and discussion.

The requirements to be met in the process of modeling of professional situations: compliance with certain goals (formation of knowledge on the topic, development of ability to analyze complex problems; education of a sense of responsibility for their decisions, moral and personal qualities, etc.); compliance with the level of complexity of students' learning opportunities; illustration of typical situations from the real facts of professional activity; use of discussion method; variability of decisions of a situation are pointed out.

\section{1. Вступ}

Інтеграція України в європейський простір передбачає становлення якісно нової парадигми вищої технічної освіти, посилення зв'язків зі світом праці, розвиток міжкультурних відносин. Тому для майбутніх інженерів відкриваються нові можливості та перспективи співпраці із зарубіжними партнерами, що передбачає розширення меж проникнення в іншомовну культуру, розвиток діалогу різних культур. Відповідно такі обставини вимагають змін у підході до вивчення іноземних мов, оскільки вдала професійна діяльність значно залежить не лише від володіння фахівцями професійними компетенціями, але й від вільного спілкування іноземною мовою, знання норм комунікативної поведінки й етикету, особливостей культури, з представниками якої налагоджуються ділові відносини та здатність до міжкультурного спілкування в професійній сфері.

Особливості формування іншомовної комунікативної компетентності досліджували в своїх роботах Г. Бородіна, М. Гез, Р. Гришкова, О. Заболотська, Р. Мартинова та ін. У центрі уваги 
Д. Бубнова, Т. Голуб, С. Коломієць, Л. Конопляник, Г. Кравчук лежить питання розробки шляхів удосконалення змісту професійно орієнтованої іншомовної підготовки майбутніх інженерів. Питання використання професійних ситуацій в процесі вивчення англійської мови розглядають С. Барсук, О. Можарська, Т. Фоменко, Г. Чепурда та ін. Менше уваги вченими приділено моделюванню професійних ситуацій на заняттях 3 англійської мови для студентів технічних спеціальностей.

Мета дослідження полягає в аналізі змісту та вимог до моделювання професійних ситуацій в процесі вивчення студентами технічних спеціальностей англійської мови. Реалізація мети потребує виконання наступних завдань: 1) визначити сутність поняття професійної ситуації; 2) обгрунтувати умови ефективного моделювання професійних ситуацій на заняттях з англійської мови в технічних закладах освіти; 3) запропонувати приклади моделювання професійних ситуацій на заняттях з англійської мови в технічних закладах освіти.

У процесі наукового пошуку використано методи аналізу, синтезу, узагальнення, систематизації, умовисновки, спостереження.

\section{2. Явище іншомовної професіоналізащії}

Вдосконалення процесу професійно орієнтованої іншомовної підготовки на сучасному етапі розвитку науки та техніки необхідно розглядати як обов'язкову складову фахової підготовки майбутніх фахівців інженерного профілю, зокрема галузевого машинобудування. Саме тому набуває широкого розповсюдження явище іншомовної професіоналізації, яке сприяє:

- збільшенню об’єму інформації зі спеціальності у процесі роботи та аналізу іншомовних джерел (когнітивно-інформаційний фактор);

- розвитку усіх видів мовленнєвої діяльності, зокрема професійно орієнтованої іншомовної комунікативної компетентності (лінгвістичний фактор);

- накопиченню знань та набуттю умінь зі спеціальності та застосуванню методів і прийомів, що активізують професійний розвиток майбутнього фахівця у процесі професійно орієнтованої іншомовної підготовки (професійний фактор); 
- врахуванню індивідуальних здібностей та можливостей у процесі досягнення певного рівня іншомовної компетентності (психолінгвістичний фактор);

- спеціалізації іншомовної підготовки у процесі поетапного оволодіння певними знаннями для конкретного рівня володіння іноземною мовою (змістовно-структурний фактор) [6, с. 105].

Ефективній реалізації явища іншомовної професіоналізації та формуванню системи компетенцій фахівців інженерної сфери сприяє моделювання професійних ситуацій у процесі іншомовної підготовки. Адже в умовах, максимально наближених до майбутньої професійної діяльності, розвивається технологія невимушеного англомовного спілкування, творча та пошукова активність студентів, як прояв їхньої ініціативності в ході розв'язання професійних комунікативних задач [11, с. 296].

Особливі вимоги до англомовного професійного спілкування ставляться до фахівців за спеціальністю 133 «Галузеве машинобудування», оскільки це спеціальність, на якій вчать не лише будувати машини, а й розбиратись у складових частинах великих промислових виробництв, розуміти будову верстатів, промислових систем та навіть літаків й космічних кораблів, вільно оперувати всіма потрібними програмами й розробляти надсучасні підходи до оптимізації промисловості, тобто здійснювати інженерну діяльність з повного циклу життєдіяльності виробів галузевого машинобудування (розробка, впровадження, наладка, дослідження, експлуатація, ремонт та утилізація) [3, с. 108].

Так, за проектом Свропейської комісії «Тюнінг» (англ. Tuning), який було розпочато у 2000 році, з метою гармонізації освітніх структур в Європі та встановлення зв'язку між результатами навчання, компетентностями та системою кредитів ECTS, велися дослідження щодо визначення спеціальних (фахових) компетентностей окремо для галузі інженерії (A Tuning-AHELO Conceptual Framework of Expected Desired/Learning Outcomes in Engineering) [14].

Відповідно до проекту до загальних знань, умінь та навичок, якими мають володіти студенти у галузі інженерії відносяться (табл. 1).

Щоб підготувати таких фахівців, потрібно на заняттях з англійської мови створити обставини, наближені до іншомовного професійного спілкування, через моделювання професійних ситуацій іншомовного спілкування. 
Таблиця 1

Концептуальна рамка очікуваних освітніх результатів в інженерії

\begin{tabular}{|c|c|c|}
\hline знання та вміння & технічний аналіз & інженерне проектування \\
\hline $\begin{array}{l}\text { - наукових і } \\
\text { математичних } \\
\text { принципів, що } \\
\text { лежать в основі } \\
\text { інженерної галузі; } \\
\text { - систематичне } \\
\text { розуміння ключових } \\
\text { аспектів та понять у } \\
\text { галузі інженерії; } \\
\text { - базові та передові } \\
\text { знання з певної } \\
\text { галузі інженерії; } \\
\text { - розуміння поняття } \\
\text { міждисциплірності } \\
\text { в інженерії }\end{array}$ & $\begin{array}{l}\text { - здатність застосовувати } \\
\text { знання та вміння } \\
\text { для визначення, } \\
\text { формулювання та } \\
\text { вирішення інженерних } \\
\text { питань використовуючи } \\
\text { різноманітні методи; } \\
\text { - здатність застосовувати } \\
\text { знання та вміння для } \\
\text { аналізу інженерної } \\
\text { продукції, процесів та } \\
\text { методів; } \\
\text { - здатність вибирати та } \\
\text { застосовувати аналітичні } \\
\text { методи та моделювання }\end{array}$ & $\begin{array}{l}\text { - здатність застосовувати } \\
\text { знання та вміння для розробки } \\
\text { та реалізації проектів, } 3 \text { метою } \\
\text { задоволення конкретних } \\
\text { потреб; } \\
\text { - знання та застосування } \\
\text { проектувальної методології }\end{array}$ \\
\hline дослідження & $\begin{array}{c}\text { інженерно-технічна } \\
\text { практика }\end{array}$ & $\begin{array}{c}\text { загальні навички } \\
\text { та вміння }\end{array}$ \\
\hline $\begin{array}{l}\text { - здатність } \\
\text { здійснювати } \\
\text { пошук літератури, } \\
\text { використовувати } \\
\text { бази даних та інші } \\
\text { джерела інформації; } \\
\text { - здатність } \\
\text { планувати та } \\
\text { проводити } \\
\text { експерименти, } \\
\text { інтерпретувати дані } \\
\text { та робити висновки; } \\
\text { - вміння працювати } \\
\text { в лабораторіях та } \\
\text { цехах }\end{array}$ & $\begin{array}{l}\text { - здатність } \\
\text { використовувати } \\
\text { відповідне обладнання, } \\
\text { інструменти та методи; } \\
\text { - здатність поєднувати } \\
\text { теорію з практикою для } \\
\text { вирішення інженерних } \\
\text { завдань; } \\
\text { - використання } \\
\text { прийнятних методів та } \\
\text { прийомів; } \\
\text { - обізнаність про } \\
\text { нетехнічні наслідки } \\
\text { інженерної практики }\end{array}$ & $\begin{array}{l}\text { - вміння ефективно працювати } \\
\text { індивідуально та в команді; } \\
\text { - використовувати } \\
\text { різноманітні методи для } \\
\text { ефективної співпраці у } \\
\text { інженерному товаристві та у } \\
\text { суспільстві загалом; } \\
\text { - демонструвати обізнаність } \\
\text { у питаннях охорони здоров’я, } \\
\text { техніки безпеки та правових } \\
\text { норм у інженерній практиці, } \\
\text { вплив інженерних рішень на } \\
\text { суспільство та навколишнє } \\
\text { середовище та дотримуватись } \\
\text { професійної етики, обов’язків } \\
\text { та норм інженерної практики; } \\
\text { - демонструвати обізнаність в } \\
\text { організації роботи з проектами } \\
\text { та ділової практики (контроль } \\
\text { ризику, управління змінами, } \\
\text { обмеженнями); } \\
\text { - усвідомити необхідність у } \\
\text { постійному самонавчанні }\end{array}$ \\
\hline
\end{tabular}




\section{3. Моделювання професійних навчальних ситуацій}

Поняття «ситуація» визначається як сукупність умов і обставин, що створюють певне становище, викликають ті чи інші взаємини людей [4]. У контексті нашого дослідження професійну ситуацію розуміємо як иілеспрямоване моделювання в процесі вивчення англійської мови професійно схожих обставин і умов розв'язання інженерно-ділових, ухвалення фахових рішень, досягнення успішного результату ділового спілкування.

Модель - це система, дослідження якої слугує засобом одержання інформації про іншу систему [2, с. 290]. Уже моделювання - один 3 методів пізнання та перетворення світу, який дістав особливо широке поширення з розвитком науки, що обумовило створення нових типів моделей. У процесі моделювання відбувається уявне розкладання реальної професійної ситуації на елементи, які тим чи іншим чином пов'язані між собою. Як метод пізнавальної й управлінської діяльності, що дозволяє адекватно й цілісно відобразити в модельних уявленнях сутність, найважливіші якості і компоненти системи, одержати інформацію про іiі минулий, теперішній і майбутній стан, можливості та умови побудови, функціонування і розвитку, розглядає моделювання О. Столяренко [10, с. 11].

Відповідно до стандарту вищої освіти за спеціальністю 133 «Галузеве машинобудування» галузі знань «Механічна інженерія» для другого (магістерського) рівня вищої освіти до компетентностей, які має набути майбутній фахівець з прикладної механіки належать системні, інструментальні та соціально-особистісні компетентності, представлені у табл. 2 [9, с. 13-15].

Зазначені у табл. 2 компетентності значною мірою формуються у процесі професійно орієнтованої іншомовної підготовки майбутніх фахівців з галузевого машинобудування. Саме у процесі вивчення дисципліни «Практичний курс іншомовного ділового спілкування» в закладах вищої технічної освіти використовуємо моделювання професійних ситуацій, у яких майбутні інженери можуть асоціювати себе 3 певною діловою особою, детальніше познайомитися з іiі функціональними обов'язками, що, в свою чергу, сприяє формуванню практичних навичок з фаху та розвитку комунікативних умінь, креативного й оригінального мислення [3, с. 115]. 


\section{Таблиця 2}

\section{Перелік компетентностей випускника}

\begin{tabular}{|c|c|}
\hline 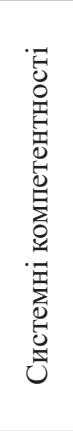 & $\begin{array}{l}\text { Здатність удосконалювати й розвивати свій інтелектуальний і культурний } \\
\text { рівень, будувати траєкторію професійного розвитку й кар'єри; } \\
\text { Здатність виявляти наукову сутність проблем у професійній сфері, } \\
\text { знаходити адекватні шляхи щодо їх розв’язання; } \\
\text { Здатність генерувати нові ідеї й нестандартні підходи до їх реалізації } \\
\text { (креативність); } \\
\text { Здатність приймати управлінські рішення, оцінювати їхні можливі наслідки } \\
\text { й брати відповідальність за результати діяльності своєї та команди; } \\
\text { Здатність до самостійного освоєння нових методів дослідження, зміні } \\
\text { наукового й науково-виробничого профілю своєї діяльності; } \\
\text { Здатність керувати проектами, організовувати командну роботу, } \\
\text { проявляти ініціативу з удосконалення діяльності }\end{array}$ \\
\hline 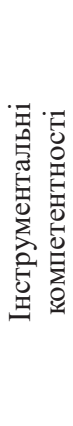 & $\begin{array}{l}\text { Здатність досліджувати проблеми із використанням системного аналізу, } \\
\text { синтезу та інших методів; } \\
\text { Здатність аналізувати, верифікувати, оцінювати повноту інформації } \\
\text { в ході професійної діяльності, при необхідності доповнювати й } \\
\text { синтезувати відсутню інформацію й працювати в умовах невизначеності; } \\
\text { Здатність пропонувати концепції, моделі, винаходити й апробувати } \\
\text { способи й інструменти професійної діяльності з використанням } \\
\text { природничих, соціально-гуманітарних та економічних наук; } \\
\text { Здатність організувати багатобічну (у тому числі міжкультурну) } \\
\text { комунікацію й управляти нею; } \\
\text { Здатність рефлексувати (оцінювати й переробляти) освоєні наукові } \\
\text { методи і способи діяльності }\end{array}$ \\
\hline 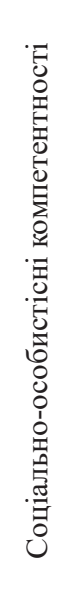 & $\begin{array}{l}\text { Здатність будувати професійну діяльність, бізнес і приймати рішення, } \\
\text { керуючись засадами соціальної відповідальності, правових та етичних норм; } \\
\text { Здатність організувати багатобічну (у тому числі міжкультурну) } \\
\text { комунікацію й управляти нею; } \\
\text { Здатність вести професійну, у тому числі науково-дослідну діяльність у } \\
\text { міжнародному середовищі; } \\
\text { Здатність використовувати соціальні й мультикультурні розходження для } \\
\text { рішення проблем у професійній і соціальній діяльності; } \\
\text { Здатність визначати, транслювати загальні цілі в професійній і } \\
\text { соціальній діяльності; } \\
\text { Здатність до усвідомленого вибору стратегій міжособистісної взаємодії; } \\
\text { Здатність транслювати норми здорового способу життя, захоплювати } \\
\text { своїм прикладом; } \\
\text { Здатність розв’язувати світоглядні, соціально й особистісне значимі проблеми; } \\
\text { Здатність орієнтуватися в системі загальнолюдських цінностей } \\
\text { і цінностей світової й вітчизняної культури. Прихильність до } \\
\text { гуманістичних цінностей для збереження й розвитку сучасної цивілізації. }\end{array}$ \\
\hline
\end{tabular}


Взявши за основу ідеї О. Бернацької [2] визначаємо фактори, які, на наш погляд, має враховувати викладач, використовуючи моделювання професійних ситуацій в процесі вивчення студентами англійської мови: рівень володіння англійською мовою студентами-майбутніми інженерами; тему і мету навчального заняття; адекватність реальної ситуації спілкування рівню готовності студентів до виконання поставлених завдань, їх можливість виявити ініціативність у виборі шляхів розв'язання дидактичної проблеми; рівень вмотивованості молоді до вивчення професійної термінології.

Професійна навчальна ситуація передбачає наявність наступних компонентів [2]) (рис. 1).

Відповідно стану розгорнутості кожного з компонентів навчальної професійної ситуації вчена виділяє такі її рівні:

- максимальний, з описом усіх компонентів ситуації;

- середній, коли умови спілкування домислюються;

- мінімальний, коли визначається лише ставлення суб'єкта до предмета розмови [2, с. 9].

У процесі викладання курсу «Практичний курс іншомовного ділового спілкування» професійні навчальні ситуації нами використовуються з метою:

- вдосконалення компетенцій англомовного читання професійних схем, інструкцій, деталей тощо; письма професійної термінології (формулювання звернень, укладання договорів тощо); говоріння та аудіювання;

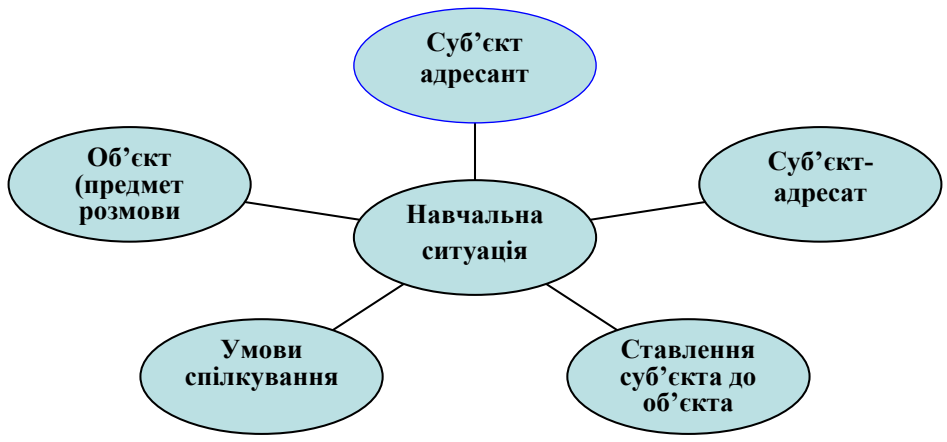

Рис. 1. Компоненти професійної навчальної ситуації (за О. Бернацькою) 
- формування здатностей вести англомовний діалог/полілог в межах професійної тематики;

- розвитку навичок роботи 3 технічними засобами в процесі вивчення іноземної мови [3, с. 118].

Суб'єктами навчальної комунікації на заняттях з англійської мови є викладач і студенти, які взаємодіють за такими моделями (рис. 2):

\section{Рис. 2. Моделі спілкування суб'сктів професійної навчальної ситуації на заняттях 3 англійської мови}

Як засвідчує аналіз рис. 2, у ході моделювання професійних ситуацій на заняттях з англійської мови взаємодія може відбуватися в таких формах: індивідуальна, фронтальна, парна, групова, кожна $з$ яких спрямовується на формування компетенцій професійного англомовного спілкування за ролями [3, с. 69]:

\section{Рис. 3. Моделі спілкування суб'єктів майбутньої професійної діяльності}

Наприклад, у ході вивчення теми «Testing. Methods» студенти іноземною мовою аналізують способи контактної взаємодії цих суб'єктів професійної діяльності [3, с. 123].

Task: Work in small groups (maximum five members). Prepare for a meeting to discuss the agenda below. Divide up the tasks. Read the appendix to the agenda below and scan all the factsheets on the opposite page. Then study your own factsheet in depth.

Student A, B, C and D: You are specialists in the four types of nondestructive testing. Scan all the factsheets on the opposite page and then study your own in depth so that you can talk about it at the meeting. 
Student E: You are the manager of the bridge and high-rise projects and you will chair the meeting. Scan all the factsheets on the opposite page and study the language tips for chairpersons on page 115.

Language tips for chairing a meeting. Here is a selection of some of the functions and language used by a chairperson.

Starting the meeting: Right. All right. I'd like to / Let's start the meeting now.

Introducing an agenda item: The first item on the agenda is ... / Let's move on to the next item (on the agenda), which is ...

Bringing in a speaker: Alison, could you give us some input here? What did you find out about this subject? Johan would you like to add anything to that? Who would like to comment at this point?

Thanking a speaker: Thank you, Alison, that was an excellent / a very interesting / an extremely useful presentation. / ... that was excellent / very interesting / extremely useful input.

Opening a discussion: Now, let's / can we throw this item open for discussion.

Closing a discussion: I think we've discussed this item enough. Let's move on (to the next item).

Summarising progress at key points: Before we continue, I'II briefly summarise what we've discussed so far.

Calling for a decision / vote: It's time for us to take a decision / decide on some action / vote for...

Ending the meeting: That concludes our meeting. Thank you very much.

Teacher's guide. Put students in small groups of no more than five members. Then tell them they are going to prepare a meeting to discuss an agenda for two projects. Focus their attention on the agenda and ask them to read the information in it. Then ask them to look at the diagrams and elicit the meaning of flaw (fault or defect). Explain that Figure A is for the bridge project and Figure $B$ is for the high-rise project. Ask them why there might be a problem performing a test in these. Then ask them to read through the appendix to the agenda. Next tell students to decide on a manager in their groups and they should read the role for Student $E$. The rest of the members of the group should read the role for students $A, B, C$ and $D$. If there are only three members in the group, you could ask a stronger student to read two of the factsheets. While the groups are preparing, it may be necessary 
to help them to assess the information gained from the factsheets and see its relevance to their preparation. Here are some ideas for helping the groups or individual students:

1) Concerning the bridge project: the magnetic particle and eddy current methods are not suitable because the flaw may be too deep, but suitable in other ways, for example that contact with surfaces is not necessary with these methods; ultrasonic and radiographic are possible, but lack of access to both top and bottom surfaces of some girders may rule out radiographic; cost may also rule out radiographic; so ultrasonic is the best option with radiographic a possibility.

2) Concerning the high-rise project: the magnetic particle method is possible for this as the flaw is close enough to the surface, perpendicular to the magnetic field flux and the material is ferro-magnetic, but with this method you need a visual inspection which may not be possible; eddy current is the most suitable because the flaw is close to the surface and at right angles to the direction of the coil winding; radiographic is possible, but not the best solution because the flaw may be too thin and parallel to $X$-rays and may not show up on the film; ultrasonic is also a poor option because the flaw may be parallel to the sound waves and may not cause enough reflection [3, c. 69-70].

Ураховуючи особливості професійного спрямування за спеціальністю галузеве машинобудування нами створюються на заняттях такі професійні ситуації, вирішуючи які студенти засвоюють різні респонсивні стратегії та тактики, оскільки респонсивні стратегії співпраці спрямовані на активний пошук вирішення адресатом способів досягнення спільної мети, задовольнити інтереси обох комунікантів (табл. 3).

Таблиця 3

\section{Класифікація респонсивних стратегій і тактик}

\begin{tabular}{|c|l|l|}
\hline 3/п & \multicolumn{1}{|c|}{ Стратегії } & \multicolumn{1}{c|}{ Тактики } \\
\hline 1. & співпраці & переконання, ствердження, пропозиція, порада; \\
\hline 2. & конкуренції & попередження, погроза, вимога, осуд, обвинувачення; \\
\hline 3. & пристосування & поступка, часткова згода \\
\hline 4. & ухилення & $\begin{array}{l}\text { уникнення відповіді на запитання, зміна теми, } \\
\text { ігнорування }\end{array}$ \\
\hline
\end{tabular}


У процесі вивчення курсу нами підібрано типові навчально-професійні ситуації, скеровані на розвиток вищеозначених стратегій. Наприклад:

Situation 1. You are a design manager at an international company. You have to determine whether the workers know how to behave in an emergency situation. If it is necessary, give them the instructions (cooperation strategy: application of persuasion techniques).

Situation 2. You are a safety manager who has to solve the problems with the complaints on the production line. Concentrate on the situations where there are complaints, anger, and crisis, identify things that can go wrong. Establish the core behavior and require for a solution or plan of action (competition strategy: application of warnings, demands).

Situation 3. You are a worker, responsible for the preparing of a construction plan. Discuss the design, proposed by an agent of the company, make alterations to the design, give reasons for your decision (adapting strategy: technique of a partial agreement).

Situation 4. You are in charge of a team of six members who has to prepare a preliminary drawing of a product. Discuss the design, proposed by the team, and try to find out the disregard of some of the notes (disregard strategy: neglect).

Ефективним засобом оптимізації навчальної діяльності в ході вивчення навчальної дисципліни $є$ ігрове моделювання, як елемент педагогічної евристики, що сприяє розвитку творчого мислення. Поряд 3 цим, ігрові форми навчання на практичних заняттях, надають можливість ефективної організації взаємодії викладача та студентів, продуктивної форми їх спілкування 3 притаманними їм елементами змагання, зацікавленості, взаємодопомоги.

Так в ході вивчення теми «Testing. Plans» моделювання професійних ситуацій дозволяє формувати вміння адекватного емоційного впливу на людей, та розвивати навики професійного спілкування. Тому використовуємо дві форми рольових ігор: керовані (Research - Using NSF website (https://www.nsf.gov/news/newsmedia/neeswood/), investigate the ways of making buildings earthquake-proof. Create a poster, presentation or information leaflet of your findings. Create a summary of your learning from NSF. Identify the number of key points raised in the session) та імпровізовані. Коли вибираємо керовану гру, заздалегідь узгоджуємо варіант 
професійної ситуації, визначаємо роль, а також складність професійної англомовної лексики спілкування. Наприклад, в процесі вивчення теми «Accidents» використовуємо такі методи, як рольові, ділові ігри, дискусія, мозкова атака.

В імпровізованих іграх розподіл ролей, ситуацій користування лексикою робиться з вільного вибору. Наприклад, тема «Accidents. Reports» дає змогу розігрувати наступні ролі професійних ситуацій: technicians, managers, workers, investigators.

Також використовуємо ігри, в яких слухачі відтворюють стандартні ситуації професійного життя і виконують статусні ролі, що не мають особистісних характеристик. Це ділові зустрічі, телефонна розмова, інтерв'ю. Під час вивчення теми «Accident. Communication» пропонуємо в ході парної роботи провести інтерв'ю (Roleplay the situation where an employee is communicating concerns to his/her senior officer or manager about a passanger plain which is taking off. The co-pilot senses that the take-off speed is too slow. But the airspeed indicator is showing 80, the correct speed. And the pilot is the captain, the senior officer) [12]. Викладач спостерігає за діяльністю студентів, фіксує помилки, але не втручається в спілкування.

Створюючи професійні ситуації, викладач звертає увагу на те, щоб завдання відображали реальні ситуації інженерної діяльності, подавали проблему під несподіваним кутом зору.

Так в ході вивчення теми «Accidents. Report» проводимо рольову гру «Аналіз нещасного випадку з літаком» студенти отримують рольові картки, в яких вказані їх імена, вік, стать, посада та посадові обов'язки фахівців аеродрому. Ставимо завдання студентам: read an investigative report, speculate and roleplay the ways of solving the problem.

\section{4. Підготовка та навчання за кейс методом}

Якщо потрібно спрямувати увагу на конкретну професійну ситуацію, застосовуємо аналіз конкретних прикладів, реальних випадків 3 життя (кейс-метод (case studies). Варто наголосити, що кейс-метод полягає в осмисленні студентами реальної професійної ситуації, опис якої водночас відображає практичну проблему, а також актуалізує комплекс англомовних компетенцій, які потрібно засвоїти при вирішенні цієї проблеми [3, с. 32]. До складу кейс-методу входять: моделювання 
(побудова моделі ситуації); системний аналіз (системне представлення й аналіз ситуації); проблемний метод (представлення проблеми, яка покладена в основу ситуаціі); уявний експеримент (засіб отримання знання про ситуацію через їі уявлене перетворення); методи опису (створення опису ситуації); ігрові методи (рольові ігри); мозковий штурм (генерування ідей щодо ситуації); дискусія (обмін думками 3 проблеми та методів її вирішення).

Нами визначено такі типів кейсів професійної діяльності інженерів галузевого машинобудування (табл. 4).

У процесі використання методу кейсів в майбутніх інженерів удосконалюються уміння аналізувати ситуації, оцінювати альтернативи, вибирати оптимальний варіант і складати план його здійснення. I якщо протягом навального циклу такий підхід застосовується багаторазово, то в студентів формується стійка навичка вирішення практичних задач. У процесі методу кейсів реалізуємо наступні фази (табл. 5).

На наше переконання, метод кейсів сприяє залученню студентів до знаходження найбільш оптимального вирішення практичних професійних завдань. Пошук найкращих шляхів виходу з ситуації спонукає студентів до дискусії, до обміну думками; мотивує формулювати власну думку, правильно iї виражати, доводити, аргументувати; вести дискусію у формі діалогу або полілогу (спільного обговорення запропонованих рішень, опонування, дискусіі). Результатом застосування цього методу є сформованість навичок самостійного проведення дослідження певній галузі професійного знання.

Поряд 3 цим, застосування професійних ситуацій в процесі вивчення майбутніми інженерами англійської мови сприяє розвитку здатності встановлення контактів з іноземними партнерами щодо постачання машинобудівної техніки, інструментів, вирішення конфліктних ситуацій тощо. Так, в ході вивчення теми «Testing» пропонуємо студентам вирішити професійну ситуацію: Prepare for a meeting to discuss agenda. You are a manager of the bridge and high-rise projects and you will chair the meeting. Conduct the meeting. Discuss the items on the agenda and reach decisions for the mentioned items.

Створення на заняттях таких навчальних ситуацій, типових до тих, які існують у професійній сфері, мотивує студентів до самовираження, й тренує уміння вести різноманітні за дискурсом та жанром типи діа- 
Таблиця 4

\section{Типи кейсів на заняттях 3 англійської мови}

\begin{tabular}{|c|c|c|}
\hline Тип кейсу & Характеристика типу & Приклади кейсів \\
\hline $\begin{array}{l}\text { Кейс- } \\
\text { випадок }\end{array}$ & $\begin{array}{l}\text { короткий кейс, який розпо- } \\
\text { відав про певний випадок; } \\
\text { його можна було використо- } \\
\text { вувати під час лекції, щоб } \\
\text { проілюструвати певну ідею } \\
\text { або поставити питання для } \\
\text { обговорення. Такий кейс } \\
\text { легко прочитують, швидко } \\
\text { сприймають і студентам не } \\
\text { потрібно було готуватися до } \\
\text { нього вдома; }\end{array}$ & $\begin{array}{l}\text { Write a SWOT analysis for a machine } \\
\text { building plant that you are familiar } \\
\text { with, listing at least } 5 \text { strengths, } \\
\text { weaknesses, opportunities and threats. } \\
\text { Write down as many things as you can } \\
\text { think of about SWOT analysis in } 60 \\
\text { seconds. }\end{array}$ \\
\hline Кейс-вправа & $\begin{array}{l}\text { дає змогу використовувати } \\
\text { на практиці отримані } \\
\text { навички; найчастіше } \\
\text { вправи використовувались } \\
\text { при кількісному аналізі } \\
\text { ситуації; }\end{array}$ & $\begin{array}{l}\text { Working in a small team, go through } \\
\text { the R\&D stages for the creation of a } \\
\text { new technology: } \\
\text { - generate ideas - carry out small } \\
\text { scale research with other groups; } \\
\text { - write a product brief; } \\
\text { - determine the product specification; } \\
\text { - if possible, make a prototype of the } \\
\text { packaging; } \\
\text { - explain how you would test the product; } \\
\text { - consider the promotion that could be } \\
\text { carried out to support the launch of the } \\
\text { new product. }\end{array}$ \\
\hline $\begin{array}{l}\text { Кейс- } \\
\text { ситуація }\end{array}$ & $\begin{array}{l}\text { класичний кейс, який } \\
\text { вимагав від студентів } \\
\text { глибокого і детального } \\
\text { аналізу ситуації; в цьому } \\
\text { випадку ставилося } \\
\text { запитання, на яке мали дати } \\
\text { відповідь студенти, а тому } \\
\text { зазвичай кейс-ситуація } \\
\text { потребувала часу для } \\
\text { детального ознайомлення і } \\
\text { попередньої підготовки. }\end{array}$ & $\begin{array}{l}\text { You are the Chief Director for a large } \\
\text { software manufacturer in the UK. The } \\
\text { business currently sells a range of } \\
\text { software. The products are distributed } \\
\text { around England, Scotland and Wales. } \\
\text { Put together a report explaining how } \\
\text { the firm could grow using each of the } \\
\text { four strategies in Ansoff's Matrix. For } \\
\text { each strategy: } \\
\text { - define it; } \\
\text { - explain how the company could use } \\
\text { the strategy - use specific examples; } \\
\text { - give the level of risk associated with } \\
\text { the strategy. } \\
\text { At the end of the report, recommend } \\
\text { one strategy that the firm should } \\
\text { move forward on. Justify your } \\
\text { recommendation. } \\
\text { Create a mind map of your learning } \\
\text { about Ansoff's Matrix. This can be } \\
\text { done by hand, on computer or using an } \\
\text { appropriate mobile device app. }\end{array}$ \\
\hline
\end{tabular}


Таблиця 5

Підготовка і навчання за кейс-методом

\begin{tabular}{|c|c|c|}
\hline Фаза роботи & Дії викладача & Дії студента \\
\hline До заняття & $\begin{array}{l}\text { 1. Підбирає кейс. } \\
\text { 2. Визначає основні та } \\
\text { допоміжні матеріали для } \\
\text { підготовки студента. } \\
\text { 3. Розробляє сценарій } \\
\text { заняття. }\end{array}$ & $\begin{array}{l}\text { 1. Отримує кейс і список } \\
\text { рекомендованої літератури. } \\
\text { 2. Індивідуально готується до } \\
\text { заняття }\end{array}$ \\
\hline $\begin{array}{l}\text { У процесі } \\
\text { заняття }\end{array}$ & $\begin{array}{l}\text { 1.Організовує попереднє } \\
\text { обговорення кейсу. } \\
\text { 2. Ділить академічну групу } \\
\text { на підгрупи (команди). } \\
\text { 3. Керує обговоренням кейсу } \\
\text { в підгрупах, забезпечує } \\
\text { додатковою інформацією }\end{array}$ & $\begin{array}{l}\text { 1. Ставить запитання щодо } \\
\text { поглиблення розуміння кейсу та } \\
\text { проблеми. } \\
\text { 2. Розробляє варіанти рішень, } \\
\text { вислуховує думки колег-студентів } \\
\text { 3. Приймає особисто, або бере } \\
\text { участь у прийнятті колективного } \\
\text { рішення. }\end{array}$ \\
\hline Після заняття & $\begin{array}{l}\text { 1. Оцінює роботу кожного } \\
\text { студента та підгруп в цілому. } \\
\text { 2. Оцінює прийняті рішення } \\
\text { на поставлені запитання. }\end{array}$ & $\begin{array}{l}\text { 1. Складає письмовий звіт про } \\
\text { заняття та свою участь у ньому. } \\
\text { 2. Накопичує інформацію для } \\
\text { використання в кейсах з інших } \\
\text { дисциплін. }\end{array}$ \\
\hline
\end{tabular}

логів, виконувати різні ролі, дотримуючись лінгвістичних і соціокультурних стандартів, удосконалювати різні комунікативні стратегії 3 метою успішної реалізації комунікативних намірів.

Метод кейсу дає змогу отримати навчальні результати, пов'язані із засвоєнням знань і навичок (засвоєння нової інформації; вибір методів збору даних; застосування методів аналізу; уміння працювати з текстом) і освітні результати, створені самими учасниками взаємодії, реалізовані особисті цілі навчання (створення певного продукту; постановка та досягнення особистих цілей; підвищення рівня професійної компетентності, набуття досвіду прийняття рішень, дій у новій ситуації, вирішення проблем) [5, с. 305].

\section{5. Висновки}

Отже, професійну ситуацію розуміємо як цілеспрямоване моделювання в процесі вивчення англійської мови професійно схожих обставин і умов розв'язання інженерно-ділових, ухвалення фахових рішень, 
досягнення успішного результату ділового спілкування. Використання моделювання професійних ситуацій у процесі вивчення дисципліни «Практичний курс іншомовного ділового спілкування» в закладах вищої технічної освіти сприяє розвитку в майбутнього фахівця здатності асоціювати себе з певною діловою особою, яка чітко й професійно виконує свої функціональні обов'язки. А це сприяє формуванню комунікативних умінь, творчого мислення й безумовно практичних англомовних професійних навичок спілкування в повному розумінні цього поняття (комунікативного, інтерактивного й перцептивного аспектів).

У процесі моделювання професійних ситуацій необхідно дотримуватися таких вимог: відповідність визначеним цілям (формування знань 3 теми, розвиток здатностей аналізу складних проблем; виховання почуття відповідальності за свої рішення, моральних особистісних якостей тощо); відповідність рівня складності навчальним можливостям студентів; ілюстрування типових ситуацій з реальних фактів професійної діяльності; використання прийому дискусії; варіативність вирішення ситуації.

Моделювання професійних ситуацій у процесі іншомовної підготовки майбутніх фахівців з галузевого машинобудування сприяє активізації пізнавальної діяльності майбутніх фахівців; інтенсифікації освітнього процесу, що в свою чергу, дає змогу уникнути одноманітності та мотивує до вивчення дисципліни; формуванню навичок іншомовного професійного спілкування в штучно створених ситуаціях, максимально наближених до реальних умов професійного середовища.

За нашим переконанням, у ході розв'язання професійних ситуацій відбувається апробація зразків і моделей реального спілкування іноземною мовою, формується комунікативна поведінка студентів, тобто проектується і реалізується ідеальне уявлення про можливу й належну норму професійної діяльності для досягнення мети.

\section{Список літератури:}

1. Барсук С. Л. Педагогічні умови формування іншомовного професійного мовлення майбутніх судноводіїв на засадах комунікативно-когнітивного підходу : дис... канд. пед. наук : 13.00.04. Херсон, 2016. 253 с.

2. Бернацька О. В. Моделювання ситуацій професійної діяльності у навчанні іноземної мови у вищому навчальному закладі військового профілю : дис.. ... канд. пед. наук : 13.00.04. Київ, 2004. 181 с. 
3. Галацин К. О., Хом’як А. П. Інтерактивні технології формування комунікативної культури майбутніх фахівців у процесі вивчення англійської мови : навч.-метод. посіб. Луцьк : Вежа-Друк, 2019. 160 с.

4. Гончаренко С. У. Український педагогічний словник. Київ : Либідь, 1997. $376 \mathrm{c}$.

5. Краснопольський В. Е. Іншомовна підготовка студентів нефілологічних спеціальностей на основі створення і використання web-технологій : дис. ... д-ра пед. наук : 13.00 .01 . Київ, 2019. 438 с. с. 305

6. Крупченко А. К., Кузнецов А. Н. Основы профессиональной лингводидактики : монография. Москва : АПКиППРО, 2015. С. 105.

7. Лукянець М. Г. Класифікація респонсивних стратегій і тактик (на матеріалі англомовного діалогічного дискурсу). Науковий вісник кафедри Юнеско КНЛУ. Серія Філологія. Педагогіка. Психологія. 2015. Випуск 30. С. 213-218.

8. Методи та засоби підвищення мовленнєвих компетенцій з іноземної мови в практичній діяльності майбутніх економістів: колект. наук. монографія / за заг. ред.: О. В. Керекеши. М. : Вид. «Атлант ВОИ СОИУ», 2017. 147 с.

9. Освітні програми: Рекомендації до розроблення [Текст] / Уклад. В. П. Головенкін. Київ : КПІ ім. Ігоря Сікорського, 2018. С. 13-15.

10. Столяренко О. В. Моделювання педагогічної діяльності у підготовці фахівця : навчально-методичний посібник. Вінниця : ТОВ «Нілан-ЛТД», 2015. $196 \mathrm{c}$.

11. Чепурда Г. Створення комунікативних ситуацій та використання ділової гри на заняттях $з$ ділової англійської мови. Гуманітарна освіта в технічних вищих навчальних закладах. Київ, 2014. № 30. С. 294-303.

12. Bonamy D. Technical English 4. Coursebook. Pearson Education Limited, 2011. 127 p.

13. OECD A Tuning-AHELO Conceptual Framework of Expected Desired/ Learning Outcomes in Engineering. OECD Education Working Papers. 2011. No. 60. URL: http://dx.doi.org/10.1787/5kghtchn8mbn-en (accessed 14 February 2021).

14. Tuning Education Structures in Europe. 2nd Edition. 2008. URL: http://www.unideusto.org/tuningeu (accessed 14 February 2021).

\section{References:}

1. Barsuk S.L. (2016) Pedaghoghichni umovy formuvannja inshomovnogho profesijnogho movlennja majbutnikh sudnovodijiv na zasadakh komunikatyvno-koghnityvnogho pidkhodu [Pedagogical conditions for the formation of foreign language professional communication of future navigators on the basis of communicative and cognitive approach] ( $\mathrm{PhD}$ Thesis), Kherson.

2. Bernacjka O.V. (2004) Modeljuvannja sytuacij profesijnoji dijaljnosti u navchanni inozemnoji movy u vyshhomu navchaljnomu zakladi vijsjkovogho profilju [Modeling of situations of professional activity in teaching a foreign language in a higher educational institution of military profile] ( $\mathrm{PhD}$ Thesis), Kyiv.

3. Ghalacyn K.O., Khom'jak A.P. (2019) Interaktyvni tekhnologhiji formuvannja komunikatyvnoji kuljtury majbutnikh fakhivciv u procesi vyvchennja anghlijs- 
jkoji movy [Interactive technologies of formation of communicative culture of future specialists in the process of learning English]. Lucjk: Vezha-Druk. (in Ukrainian)

4. Ghoncharenko S.U. (1997) Ukrajinsjkyj pedaghoghichnyj slovnyk [Ukrainian Pedagogical dictionary]. Kyiv: Lybidj. (in Ukrainian)

5. Krasnopoljsjkyj V.E. (2019) Inshomovna pidghotovka studentiv nefilologhichnykh specialjnostej na osnovi stvorennja i vykorystannja web-tekhnologhij [Foreign language training of students of non-philological specialties based on of creation and use of Web technologies]. (PhD Thesis), Kyjiv.

6. Krupchenko A.K., Kuznecov A.N. (2015) Osnovy professional'noj lingvodidaktiki [Fundamentals of Professional Linguodidactics] Moskva: APKiPPRO. (in Russian)

7. Lukjanecj M.Gh. (2015) Klasyfikacija responsyvnykh strateghij i taktyk (na materiali anghlomovnogho dialoghichnogho dyskursu) [Classification of responsive strategies and tactics (based on English dialogic discourse)]. Naukovyj visnyk kafedry Junesko KNLU. Serija Filologhija. Pedaghoghika. Psykhologhija, vol. 30. Kyiv, pp. 213-218.

8. Kerekesha O.V. (ed.) (2017) Metody ta zasoby pidvyshhennja movlennjevykh kompetencij z inozemnoji movy $v$ praktychnij dijaljnosti majbutnikh ekonomistiv [Methods and means of improving of foreign language speech skills in the practical activities of future economists]. M.: Vyd. "Atlant VOY SOYU». (in Ukrainian)

9. Gholovenkin V.P. (2018) Osvitni proghramy: Rekomendaciji do rozroblennja [Educational programs: Recommendations for development]. Kyiv: KPI im. Ighorja Sikorsjkogho. (in Ukrainian)

10. Stoljarenko O.V. (2015) Modeljuvannja pedaghoghichnoji dijaljnosti u pidghotovci fakhivcja [Modeling of pedagogical activity in specialist training] Vinnycja: TOV «Nilan-LTD». (in Ukrainian)

11. Chepurda Gh. (2014) Stvorennja komunikatyvnykh sytuacij ta vykorystannja dilovoji ghry na zanjattjakh z dilovoji anghlijsjkoji movy [Creation of communicative situations and use of case studies at classes of Business English]. Ghumanitarna osvita $v$ tekhnichnykh vyshhykh navchaljnykh zakladakh, no. 30. Kyjiv, pp. 294-303.

12. Bonamy D. (2011) Technical English 4. Coursebook. Pearson Education Limited.

13. OECD (2011) A Tuning-AHELO Conceptual Framework of Expected Desired/Learning Outcomes in Engineering. OECD Education Working Papers, No. 60, OECD Publishing. Retrieved from: http://dx.doi.org/10.1787/5kghtchn8mbn-en

14. Tuning Education Structures in Europe (2008) ( $2^{\text {nd }}$ ed.). Retrieved from: http://www.unideusto.org/tuningeu 